\title{
FICÇÃO E ALIENAÇÃO MODERNISTAS: REPRESENTANDO O ISOLAMENTO SOCIAL E A INCOMPLETENNCIA DAS NECESSIDADES HUMANAS EM MISS BRILL E LIFE AND DEATH IN THE SOUTH SIDE PAVILION
}

\author{
MODERNIST FICTION AND ALIENATION: REPRESENTING SOCIAL \\ ISOLATION AND INCOMPLETENESS OF HUMAN NEEDS IN MISS BRILL \\ AND LIFE AND DEATH IN THE SOUTH SIDE PAVILION
}

\author{
Muhammad Imran \\ School of Foreign Languages, Shanghai Jiao Tong University, China \\ imranjoyia76@gmail.com
}

Samina Akhtar

School of Foreign Languages, Shanghai Jiao Tong University, China imranjoyia@sjtu.edu.cn

\begin{abstract}
Resumo: Este artigo tem como objetivo analisar a ideologia da alienação na ficção modernista, incorporada ao isolamento social e à incompletude das necessidades humanas em Miss Brill, de Mansfield, e Life and Death, de Carey, no pavilhão do lado sul. Embora Mansfield e Carey pertençam a duas épocas; modernos e pós-modernos, mas apresentam o conceito de alienação social e incompletude das necessidades humanas básicas de maneira semelhante. Seus esboços de personagens de Miss Brill e Shepherd de $3^{\text {a }}$ classe relacionam a alienação com a falta de amor e pertencimento, por um lado, enquanto a auto-estima e os desafios das atitudes capitalistas, metrópoles e industriais, por outro. Portanto, este artigo explora como a Miss Brill e a Shepherd 3rd class refletem a vida das pessoas envolvidas em solidão, alienação, separação e afetadas pela globalização e industrialização, especialmente pela urbanização do início e meados do século 20.
\end{abstract}

Palavras-chave: Alienação; Desorientação; Isolamento Social; Impotência; Auto-estima; Hierarquia de Necessidades

\begin{abstract}
This paper aims to analyze the ideology of alienation in modernist fiction as embedded in social isolation and incompleteness of human needs in Mansfield's Miss Brill and Carey's Life and Death in the South Side Pavilion. Although, Mansfield and Carey belong to two eras; modern and postmodern but they present the concept of social alienation and incompleteness of basic human needs in similar ways. Their character sketches of Miss Brill and Shepherd 3rd class link alienation with the lack of love and belongingness, on one hand, while self-esteem and challenges of capitalist, metropolis and industrialist attitudes on the other hand. Therefore, this paper explores that how both Miss Brill and Shepherd 3rd class reflect the life of the people entangled in solitude, alienation, separation, and affected by globalization and industrialization especially urbanization of the early and mid of the 20th century.
\end{abstract}

Keywords: Alienation, Disorientation, Social Isolation, Impotence, Self-esteem, Hierarchy of Needs 


\section{Introduction}

Alienation as a universal existential dilemma has been an inevitable and central fact of all human existence. According to this term "alienation", the modern human being feels a sense of displacement, living in a chaotic and fragmented world. In such a situation, it seems progressively harder for humans to be able to find order and meaning in life. Therefore, alienation is the degree to which a person feels powerless to achieve the role he/she has determined to be rightfully attained in specific situations (Clark 849). This ideology, rooted in existentialism, has had some repercussions in modern literature as well. Much of twentiethcentury literature has dealt with the recurrent theme of alienation generally and its sub-theme social isolation in particular. Many writers such as James Joyce in Portrait of the Artist as Young Man, Ralph Ellison in Invisible Man, Albert Camus in Meursault (The Stranger), T.S. Eliot in The Love Song of J. Alfred Prufrock, Henrik Ibsen in his play A Doll's House, Katherine Mansfield in her short fiction and Peter Carey also in his collection of stories The Fat Man in History has adopted the concept of alienation as confusion, meaninglessness, frustration, dispossession and disintegration. The present article aims to expose the sense of alienation caused through social isolation and incompleteness of human basic needs in modern fiction of Katherine Mansfield's Miss Brill and Peter Carey's Life and Death in the South Side Pavilion through the theoretical lens of Clayton Alderfer's ERG theory (Existence, Relation and Growth) which is a revised version of Abraham Maslow's theory of Hierarchy of Needs.

Katherine Mansfield highlights the situation of women in the age of anxiety and points out the causes and effects of the age and lonely life in the early $20^{\text {th }}$ century. She focused her message through fiction on the lives of the individuals and depicted accurately the alienation of individuals through various angles. She sought alienation not only about social or economic conditions nor to any divine powers but concerning other alienated individuals. This is might be because of her interaction with the cultural climate in which she lived as her life exhibits a struggle to establish a meaningful and productive existence in spite of alienation (Middleton 1966:8).

While Peter Carey's short fiction presents the early second half of the $20^{\text {th }}$ century through common themes of social isolation, the ravages of consumer capitalism and debunking of New Age myths, gender and sex issues and the alienation of individuals as well. Usually, Carey's characters are entrapped either come to an impasse or find themselves in situations they are not responsible for and ultimately, nevertheless have to bear those circumstances. In so doing, some of Carey's characters rebel against their living conditions hopelessly whereas most of them accept their miseries, misfortunes, and the incompleteness of basic desires as destiny. Carey himself confessed in an interview that, "my stories made me tense and ill and I wept for the fate of these poor bloody losers" (Carey 1973:35).

The ideology of alienation, according to Carey, is the direct product of capitalism. In an interview with Philip Neilsen, Carey claimed that

we are alienated from each other, from ourselves, work, from our environment. We are denied access to information and given misinformation instead. We are raised within an authoritarian system and teach our children to look for leaders. [....] I don't think people are mindless or stupid and no matter how fucked around we are by the vales of late capitalism, I still think there is some residual human decency in most of us (Carey 1987:72).

Through his short fiction, he highlighted the effects of industrialization and globalization on the life of the common people and the effect of the culture of big enterprises on the lives of common masses respectively after WWII. 
Mansfield and Carey's selected short stories for this essay represent both the genders from modern and postmodern perspectives of the $20^{\text {th }}$ century Australian and New Zealand originated fiction. They have been written in a quiet allegorical way about the psychological, physical and sexual issues of men and women. For the better understanding of the study, Alderfer's ERG (Existence, Relatedness and Growth) theory along with Maslow's Hierarchy of Needs theory, as the first one is the revised version of later one, have been adopted for theoretical foregrounding to understand the intensity and severity of the alienation in different shapes present in the lives of the characters in the selected short stories. The methodology process for this article is to have a close textual reading of the selected short stories and analysis of the protagonists with the application of ERG and Hierarchy of Needs theories and other critics such as psychoanalysis arguments and the interpretations of metropolis and industrialization have been focused during textual analysis.

Every person struggles to meet the required needs of a balanced life and the search for those elements becomes hard at certain moments in life where it seems extremely hard to get the way out. Various factors play a crucial role in this struggle for balanced existence in society and the absence of these factors and elements make life more disastrous and lead towards the endless strangeness and alienation. According to Maslow's theory of Hierarchy of Needs, the basic five needs of every human being are: 1) biological and physical needs such as food, house, rest, sex etc., 2) safety needs such as security, stability and ultimate freedom from any kind of consistent and inconsistent fear, 3) love and belongingness needs such as affection and love, intimacy, acceptance, trust, friendship and the most crucial one is affiliation with a unit of any kind like society, family or with colleagues in any company, 4) esteem needs such as esteem for self like independence, achievement, hold, dignity and honor while esteem from others is expected like respect, praise, recognition, status and the most important reputation, 5) self-actualization needs such as realization of personal potential, personal growth, self-fulfillment and the most desired in such needs is to become everything one is capable of becoming. (Maslow 1970)

The modern literature has a widespread atmosphere of alienation where modern man has been seen entangled in different issues of alienation. So to grasp, all the issues, ideas, and thoughts the man has been facing or face, is very difficult to address which are related to man and his alienation from himself, his fellow human beings, his society in which he lives and his God (Imran and WEI, 2019). According to Tonnies (1987), modernity is associated with the characteristic that it has shattered the traditional bond of communities and extended kinship concepts. Many other modern social scientists are of the view that alienation is linked with modern life and its anomic and isolated nature (Seeman 1975) and Wellman (1979) says that it's a lost community hypothesis as it had been a hot issue of debates in early American sociology talks. However, Luis Wirth (1938) has commented that the literature of the 1930s has discussed too much about population density, cultural heterogeneity and specialization of modern city life under minded community and family bonds which became the cause of isolation. Karl Max's explanation of alienation supports Peter Carey's notions about a man and his social isolation by giving arguments in the following lines:

It is man, then, who is at the foundation of Marx's considerations; and to be more precise: man "alienated from himself." This "alienation" is, according to Marx, one of the pillars of the actual bourgeois society, the center, consequently, from which all his reflections will radiate... ( Braunschweig 504)

\section{Shepherd 3rd Class and Alienation}

Throughout the story, it is observed that the trapped condition of the Shepherd 3rd Class in a capitalist structure which made him alienated from the rest of society. According to 
Schulze (2005), its Peter Carey's major focus to highlight the economic and social system issues of the present age which has a corruptive and alienating effect on the life of the individuals (Schulze 121). These remarks show that the protagonist's entrapment and alienation are due to the consequences of the capitalist attitude of the company and he is forced to remain in the inescapable and restrictive situation. According to Schulze (2005), although Carey would welcome more self-responsibility, he also has recognized that the globalized world has a restrictive rather than stimulating effect on individuals' development (Schulze 122).

Peter Carey's ways of dealing with the imprisonment of an individual and his/her alienation from the other world are based on his dystopian scenarios. According to Hassall (1994), these dystopian scenarios are called "hellish worlds" because the sufferings and entrapment of the central figure are based on manifold types and ranges such as the unexplained role or duty of stopping the horses falling into the pool. Furthermore, the protagonist is unable to make sex with Marie, his girlfriend, and relating this inability with the death of the horses is evidence of the protagonist's incapability of handling the situation through his mind and body.

In Life and Death in the South Side Pavilion the protagonist is simply an employee of a very big company that knows nothing about the critical situation of the workers in far of places away from the urban life. Carey makes the protagonist more critical by employing his artistic techniques that his employment in itself is alienation for him. There is no name of the company as Carey has used the only common noun "the company" throughout the story and his position is described as "Shepherd 3rd Class" again without any proper name is also alienation. He is labeled as a shepherd but his task is opposite to his position title. He has been asked to take care of the horses instead of sheep, it's like his authority to tackle sheep is changed with an anonymous company. Alienation at every step is there to welcome the protagonist as after the disclosure of his job title and the task assigned to him, readers also become confused and insecure about his position in company and task for which he has been recruited. According to Hassall (1994), the protagonist in this story is an unknown capitalist prisoner who is a victim of isolation and alienation of an unknown company that seems to represent his only contact with an external world (Hassall 17).

From Shepherd 3rd Class's alienation, it seems that Carey wants to criticize Hegelian philosophy. Hegelian, a French Philosopher Hegel's followers, has the routine in their production houses and factories that with more and more width of the company and its expansion specifically during the industrial revolution, the employees lost their connection to the end product and with the leading heads. At such moments, the individuals have to accept the situation by finding no other means expect to escape. In an interview, Peter Carey explained that:

\footnotetext{
We are alienated from each other, from ourselves, from our environment. We are denied access to information and given misinformation instead. We are raised within an authoritarian system and teach our children to look for leaders....I don't think people are mindless or stupid and no matter how fucked around we are by the values of late capitalism. I still think there is some residual human decency in most of us. (qtd in Schulze121)
}

Shepherd 3rd Class looks forward to the response from the company head office throughout the story and during this time his function seems to like an ignorant from his duties, company's policies, nature of responsibilities and at last his alienated position which makes him detached from his every sense of achievement; professional as well sexual. 
Shepherd 3rd Class's alienation from his company and position in pavilion makes him a victim of psychosomatic state and he assumes that his making love with Marie becomes the cause of death of horses.

'EVERY TIME I FUCK MARIE I KILL A HORSE’ (56)

The narrator's physical and mental state deteriorates when he recognizes that each act of love with Marie causes a further death because he is neglectful of his duties. He has made his mind that his action of making love with Marie gives the reaction in the result of the death of a horse in the pool. This self-assumed theory of association of lovemaking with the death of horses leads the narrator in more complexes and deteriorating mental state with results in the worst situation than the fact of alienation.

His physical and psychological impotence made him sexually impotent and his belief developed so strong in his mind that while lying with his girlfriend he fails to get an erection and becomes no longer able to make sex with her.

And now that I'm unable to make love she thinks it is because I have an unnatural attraction to the horses and that I find her unattractive in comparisons. But I'm unable to make love because every time I make love a horse falls into the pool (56).

He decides to restrict from making love as he seems trapped in his dilemma of deterioration of mind and body as both of them are severely stilted by the lack of significant job perspectives in an unresponsive company. Here "the company" becomes the more crucial element in making the narrator a powerless and victim of loneliness throughout the story by being representative of late capitalist ideology. The irresponsive attitude of the company not only made him alienated from his job task at the pavilion but also his natural desire for sex and the strong stimulus for sex; Marie.

In this context of power and powerlessness, Carey comments explicitly on gender relations. Marie asks the narrator to leave the company as she needs his attention and he is upset due to the death of horses. He seems much passionate about horses and Marie tries to make him able to come out from that entangled situation. One day when she comes to see him in the pavilion finds him weeping and she inquires;

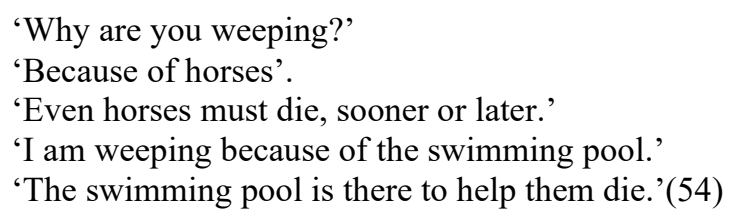

She tries much to make him convinced that he isn't the reason for the death of horses and tries to boast him but all her efforts remain fruitless even though he admits Marie's arguments are valid. He is in a state of hamartia about his decisions and actions. Marie tries to prove to be an external influence upon him to make him able to decide and shatter his false adherence to the taboo of death of horses with the lovemaking process. However, he is revolving around his physical and mental impotence as he claims;

'I AM HERE TO STOP THE HORSES FALLING INTO THE SWIMMING POOL'. (54)

Marie is the person, who helped him to get a job in the pavilion and now she is insisting on him to leave that job. He sends his resignation to the company and asked for relieving from the shepherd 3rd class job but wouldn't get any answer from the company. 
Marie asks him to leave the company without any formal resignation by saying that "Fuck the Company" (54). And this tension between them becomes the reason that Marie gives him to choose either choose horses or her. She asks repeatedly that do you love horses and he always replies in negative and confirms his love with her. She very often helps him to understand the fact that he can't do anything by stopping them from falling into the pool. At last Marie gives him an ultimatum;

She arrived today with colour brochures and an ultimatum: either I leave the horses or she will leave me. (54)

The company's alienated attitude from its worker, Shepherd 3rd Class, has made him mentally upset and alienated from his job, personal life and his affair with Marie. It made him sexually alienated from the natural process of erection a man can easily get by lying with a seductive and beautiful lady but for the narrator, it's all in vain. He finds himself trapped in his useless position at the pavilion-like in the waiting loop and wouldn't be able to find a way to escape from that entrapment of physique and mind.

Here Marie is playing the role of his counterpart as she helped him to get this job and now forcing him to get rid of it, she is quick in decision making and not timid like him. She is an independent lady and self-determined and free in making her choices, unlike the narrator. She even tries to awake himself by encouraging him and make him recover his attraction towards her by giving him colored brochures with pictures of beautiful ladies on a beach to stimulate him and his sexual impotence. He admits the influence of the brochures on him.

I leaf through the brochures she left for me; staring at the beaches [....] I have never seen so many beaches. On the beaches, there are beautiful girls, girls more beautiful than Marie. Perhaps she thinks that the beautiful girls in the brochures will provide the extra incentive. (56)

She wants him to come out from his self-imposed entrapment of mind and body with his false theory of association of his sexual power with the existence of horses. She even urges him to leave the horses and escape with her from that dreadful pavilion but again his lack of decisive courage makes him unable to take any solid step and remains unable to leave the horses, the pavilion and his alienation.

Here his attitude not to leave the company and escape with Marie remains ambiguous and unclear. It seems that he has developed an unnatural attraction towards the horses, to be insane about his concerns towards horses or his irrational and absurd loyalty with the company forced him to remain in the pavilion rather alienation.

\footnotetext{
But now I'm responsible for the horses. Each death is my responsibility and I have no wish to be responsible for so many deaths. And now that I'm unable to make love she thinks it is because I have an unnatural to the horses and that I find her unattractive in comparisons. But I'm unable to make love because every time I make love a horse falls into the pool. (56)
}

He admits that he has some sort of unnatural attraction towards the horses which makes him unable to love Marie. For him, lovemaking is an unsatisfactory thing while to save the lives of the horses is more important for him. He also describes the reason for his dissatisfaction as according to him the horses don't like the sound they produce during lovemaking and they become panic and lose their temper. Here "horses" can be interpreted as male sperms produced during intercourse. And the pool is like the female body where the horses; sperms are dropping and being wasted. As the horses are useless after drowning into the pool, the same happens with the narrator's sperms during intercourse with Marie they all 
are going to be wasted as no production is expected from this natural process in the shape of Marie's unwillingness to be pregnant.

When Marie eventually leaves him, the narrator's physical and emotional state improves. As manliness is restored, his urge to escape from his imprisonment becomes stronger, and his carefulness gives way to indifference. An attempt to breakdown the circle of absurdity and in doing so he wishes to drive all the horses into the pool. Marie's absence makes him more desirous and passionate for sex it seems her absence has restored his sexual impulse.

Another night without Marie. Her absence has cured my limp cock more quickly and affected than either of us have guessed. I tossed and turn in my tangled dreaming of involved and passionate love on the distant beaches of brochures. At this moment I am prepared to fuck until the pool is full of horses. (57)

He has become extremely ambitious to his sexual desire after Marie that he even forgot to think about the death of the horses about which he was much concerned in Marie's presence. The critical point is that the new erected thoughts of sex and power in him after Marie make him completely forgettable about his alienation and loneliness and so-called love for horses and absurd loyalty with the company. Marie's absence and thoughts cast their strong effect on him and being kept hunted by sexual thoughts of making love with her become the cause of motive behind the force to drive all the horses into the pool with full force. Shepherd 3rd Class accepts "At this moment I am prepared to fuck until the pool is full of horses" (57). According to Hassall (1994), the narrator is a frenzied attempt to escape by making him redundant (Hassall 17). All his efforts to escape from that pavilion remain fruitless and instead of responding his letters to the company, the company has sent twelve more horses in the pavilion. He remains powerless and alienated because only independent can take steps ahead to make their decisions strong. In the end, Marie also leaves him and he remained where he was, alone, alienated, and sexually frustrated in an alone pavilion.

\section{Miss Brill and her alienation}

In the short story of Miss Brill, the character of Miss Brill is Katherine Mansfield's one of the best literary sketches of a woman in the age of anxieties and metropolis life. Miss Brill is depicted as a middle-aged figure, a spinster, who didn't have the husband or not married yet. She is pictured as an alienated, psychologically complex woman with an attitude of artistic vision, childish will and eavesdropping who can imagine but in an indifferent way which becomes her dilemma at the end.

Miss Brill's alienation is caused due to the absence of the Hierarchy of Needs theory components and the most needed components which become the cause of her alienation are a desire for friendship, belongingness, love, sex, and self-esteem. She is not only the victim of alienation but also suffered from psychological disillusionment of her ideas about the dehumanized world. Her life is the victim of alienation and loneliness which led her towards frustration and let's find out the causes of her alienation and more than this alienation; her psychological and physical deprivation.

According to Maslow's five levels of human needs, the first one is biological and physical needs and those are air, water, home, sleep, food, clothes, health, exercise and the most important is sex. When we observe the character of Miss Brill, she has almost everything with her according to physical and biological needs except sex. It's because she was a spinster and she hadn't anybody to fulfill her desire for sex and made herself relax because to have sex is as important as any other natural desire like food and water. It is also a way to get family and children who make the circle around the person to feel him/her attached with relationships and this thing prevents loneliness, alienation and frustration rather make the 
person more careful and engaged. Miss Brill looks at many couples around in the garden and wishes to be social with them and talk to them but she just can imagine and think about such things as she has grown old and now nobody will accept her as his wife/partner. Mansfield portrays Miss Brill's feeling in such a way that

And Miss Brill's eyes filled with tear and she looked smiling at all the other members of the company. Yes, we understand, we understand, she thought, though what they understood she didn't know. (3)

Everybody around her knows very well that she is an alone lady and every Sunday comes to the park to kill her leisure by looking and making her observations at others in the park especially the couples are her attraction. By looking at a young couple who were in love and the boy tried to express his love and the girl stopped the boy to doing anything romantic there at that time, is keenly observed by Miss Brill. She also wants to have the love of a husband and a romantic gossip and lovemaking in a park but her dreams shattered when the young couple passed harsh remarks about her. They didn't like the presence of the old lady at a place of romantic meeting. They said that

Miss Brill prepared to listen. 'no, not now,' said the girl. 'Not here, I can't.' 'But why? Because of that stupid old thing at the end there?' asked the boy. Why does she come here at all- who wants her? Why doesn't she keep her silly mug at home?' (4)

Mansfield has discussed in detail the matrimonial affairs in her writings which show women's desire for husbands. In her short story Bliss, Mansfield shows the alienation among husband and wife as in this story she is more concerned about the passionate feelings of Bertha for her husband and she is very sad upon losing her husband and felt alienated socially and sexually. According to T.S Eliot, this story is limited to the sudden change occurred in her feelings and her moral and social ramifications are beyond the terms of reference. (Eliot, 1934) Bertha's this situation without her husband is well described by another critic Miss Freeman that her looking at the pear tree again and again especially before dinner party and her imagination about the tree as slender in full bloom and shoes the arrival of the spring season, she also glances at yellow and red tulips which are considered as a symbol of languorous joy of the sense. Miss Freeman further commented that these natural awakenings in Bertha's character arouse sexual desire in her for her husband and she desperately needed that one (Freeman, 1927). The same case is with Miss Bill as she looks at the garden and life in it and longs for the same by admiring different aspects of the events there and live in it, from the color of the dresses to the music of the band, everything aroused the desire for to be loved by someone.

Her fur is also very symbolic of this connection. In the morning she pulls it out from the box and admires it. She thinks that this beautiful fur would help her in making an attraction towards others in the park and will work as a social contactor with other people. She thinks it a tool to be helpful for her to be social in society and also she personifies her piece if fur as an object of affection. She takes it as a valuable thing for her and considers it has a definite presence of its own instead of only an inanimate thing. According to Peter Trope, the piece of fur is:

As an alternative for the society, the affection, love, empathy, and understanding which are absent from Miss Brill's life. The fur parallels her experience; it comes out of a dark little box just as she comes out of a dark little 'cupboard' of a room. (Trope 661) 
This piece of fur is significant in her life as she takes it as living thing with her and she feels comfortable with its company as Miss Brill's personification of the fur as a "little rogue" shows that fur helps to make her comfortable in her loneliness and removes the effects of alienation for some time even in her imagination. But she is humiliated by the young couple for her fur and they mocked at her due to her silly fur.

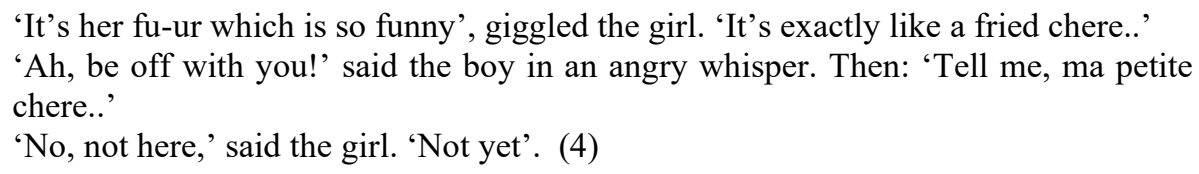

Miss Brill's attention towards the discussion of this young couple shows her keen interest in getting company male partner as she feels it as her biological need like food and air. Mansfield didn't use clear words for this aspect of Miss Brill's desire but her logging for social circle, interaction with couples, description of the garden and last but not the least her attachment with fur and the way she put it on. Mansfield in her other stories has discussed this aspect of women's need for sexual fulfillment. In her short story A Married Man's Story she writes about the alienation among husband and wife in a house. They are living in a same house live strangers and they haven't any communication to each other and this communication gap; alienation makes the husband more passionate about his wife and he thinks about her as she is standing in a kitchen:

\footnotetext{
Her head bent; with one figure she is tracing something....nothing.....on the table. It is cold in the kitchen; the gas jumps; the tap drips; it's a forlorn picture. And nobody is going to come behind her, to take her in his arms, to kiss her soft hair, to lead to the fire and to rub soft her hands warm again. Nobody is going doing out there. And she knows it. And being a woman, deep down, deep down, she does expect the miracle to happen; she really could embrace that dark, dark deceit, rather than live....like this. (Mansfield 1964)
}

Mansfield wants to convey that man and woman knows and understands very well the needs of each other. The social and sexual perspectives of life are more crucial than any other thing. In words of Kessel (1964), those who don't know how to share their feelings and experiences with others, become friends, be socializing and responding to others' interests remain isolated, alone and alienated. (134-5)

Another cause of her alienation, according to the Hierarchy of Needs, is a desire for love and belongingness; a basic factor and unit of society. She is deprived of this factor and very much visible throughout the story that she looks for social connections, admiration, love, and affection but in return, she only receives rejection and humiliation. The basic reason is her loneliness as she doesn't have family and husband with her, and to make her amused she tries to get the solace from the company of fur; a non-living object. She had the fur to get comfort but people around her made despise her fur and at this rude behavior, she becomes very sad. She also amuses herself by becoming an English tutor and reading the newspaper for old people. I think love and family are very important needs because, with love and family, we can share our feeling or arguments, also we can feel safe and comfortable around them.

The textual reading denotes the concept of loneliness and alienation and her need for family and society becomes visible from these words such as motionless, sad, chill, disappointing, yellow leaves dropping, cold, trembling smile, soundlessly, little darkroom and a faint chill, etc. These words proved to be bombarded in presenting the image of loneliness in the story which leads Miss Brill towards the hell of alienation. The very same atmosphere of loneliness and desolation is present in other short stories of Mansfield such as in Life of Ma Parker she writes; 
It was cold in the street. There was a wind like ice. People went flitting by, very fast; then men walked like scissors; the women trod like cats. And nobody knew-nobody cared. Even if she broke down, if at last, after all these years, she were to cry, she'd find herself in the lock-up as like as not. (Mansfield 1964)

To sum up, the exploration of the characters of shepherd 3rd class and Miss Brill in light of Alderfer and Maslow's theories of ERG and Hierarchy of Needs shows Carey and Mansfield's treatment of the life of the people entangled in solitude, alienation, separation, and affected by the globalization and industrialization especially urbanization of the early and mid-20th century. This article further concludes that not only women are being affected by this modern socio-capitalist milieu but men also facing the results of the same unprivileged inner voices and social multi-shaping forces demolishing them in the modern world like hypocrisy, disloyalty, corruption, materialism, and psychological and sexual issues. Through Miss Brill's character, Mansfield abstracts that solitude and alienation don't persist in itself anywhere in physical form in garden or city streets where she can immerse in her musing, imagination or through her creative art but it's a psychological state of mind or condition for her to gain courage to assert her independence despite her awareness of her socio-moral obligations. Whereas, for Shepherd 3rd Class, Carey has tried to depict the sense that selfentrapped attitude is much worst in life from any point of view either physical or psychological. Carey suggests that an understanding of existential purpose is crucial in life, and it is when we are denied such knowledge that we are isolated and disorientated. Carey's commentary of the modern world is ultimately nihilistic. He allows us to witness the isolation, absurdities and the lamentations of Shepherd 3rd Class to enable us to question if we too lack orientation in our lives or not.

\section{References}

Bennett, Bruce. Australian Short Fiction: A History. St. Lucia, Queensland: University of Queensland Press, 2002.

Braunschweig, Max. "The Philosophic Thought of the Young Marx,". In: SYKES, Gerald (Ed). Alienation: The Cultural Climate of Our Time. New York: George Braziller, 1964, p. 504.

Carey, Peter; Neilsen, Philip. "Waiting for the Barbarians: An Interview with Peter Carey". Literature in North Queensland, [s.1], n. 15 v. 3 (1987): 72.

Carey, Peter; Van Ikin, “Answers to Seventeen Questions: An Interview with Peter Carey”. Science Fiction: A Review of Speculative Literature, [s.1], n.1 v.(1), 1977: 35

Clark, John. "Measuring Alienation within a Social System". American Sociological Review, [s.1], vol. XXIV, December 1959, p. 849-852.

Freeman, Kathleen. "The Art of Katherine Mansfield”. The Canadian Forum, [s.1], vol. VII, July 1927 , p. 302-308.

Hassall, Anthony J. Dancing on Hot Macadam: Peter Carey's Fiction. St. Lucia, Queensland: University of Queensland Press, 1994. 
Imran, Muhammad. Review of The Sun and Her Flowers by Rupi Kaur. Asian Women, [s.1], vol. $34, n^{\circ} .4,2018$, p. 121-124.

Imran, Muhammad. Review of River Women, by Katherine Vermette. World Literature Today, summer 2019, p. 104.

Imran, Muhammad; Hart, Jonathan L. Review of Embroidering within Boundaries: Afghan Women Creating a future, by Rangina Hamidi and Mary Littrell. British Journal of Middle Eastern Studies, [s.1], vol. 46, n. ${ }^{\circ}$ 2, 2018, p. 335-337.

Kessel, Neil. "The Armour of Loneliness". Twentieth Century, [s.1], vol. CLXXIII, 1964, p. 134-5.

Mansfield, Katherine. "Miss Brill”. Journal of Mansfield Studies, Edinburg, Edinburg: University of Edinburg Press, 1995.

Mansfield, Katherine. The Short Stories of Katherine Mansfield. New York: Alfred A. Knopf, 1964.

Maslow, Abraham, H. Motivation and Personality. New York: Harper and Row, 1970.

Middleton, Bettye S. Alienation in The Life and Works of Katherine Mansfield. 1966. Rice University, Texas, master's thesis, p. 8.

Puzanova, Zh.V. "Filosofiya odinochestva I odinochestvo filosofa". Vestnik RUDN. Ser. Sociologiya, [s.1], no. 4-5, 2003.

Schulze, Cornelia. "Peter Carey's Short Stories. Trapped in a Narrative Labyrinth.". In: GAILE, Andreas (Ed). Fabulating Beauty. Perspectives on the Fiction of Peter Carey. Amsterdam: Rodopi Publishers, 2005, p. 117-136.

Seeman, Melvin. "On the personal consequences of alienation in work". American Sociological Review, [s.1], vol. 32, no. 2, 1967, p. 273-285.

Thomas Stearns, Eliot. After Strange Gods. New York: Harcourt, Brace, and Company, 1934.

Thorpe, Peter. “Teaching 'Miss Brill’”. College English, [s.1], vol. XXIII, 1962, p. 661-663.

Tonnies, Ferdinand. Community and Society. New Jersey: Transaction Publishers, 1988.

Wellman, Barry. "The community question: The intimate networks of East Yorkers". The American Journal of Sociology, [s.1], vol. 84, nº 5, 1979, p. 1201-1231.

Wirth, Louis. "Urbanism as a Way of Life". American Journal of Sociology, [s.1], vol. 44, no . 1, July 1938, p. 1-24. 